\title{
Pengaruh Orientasi Pasar, Inovasi Produk, dan Kapabilitas Pemasaran Terhadap Kinerja Bisnis
}

Nisa Nurul Hikmah/2301947823/LB21

Binus Business School

Management Study Program

Binus University, Indonesia

nisanurulhikmah@gmail.com

\begin{abstract}
ABSTRAK
Kinerja suatu bisnis dipengaruhi oleh banyak hal. Untuk memajukan sebuah bisnis, tentunya kita harus menganalisa factor apa saja yang dapat mempengaruhinya. Penulis mencoba melakukan penelitian apakah orientasi pasar, inovasi produk, dan kemampuan pemasaran berpengaruh terhadap kinerja suatu bisnis. Penelitian dilakukan dengan metode literature review dari beberapa jurnal internasional maupun nasional. Sebagian besar menyatakan bahwa orientasi pasar, inovasi produk, dan kemampuan pemasaran memiliki pengaruh terhadap kinerja bisnis.
\end{abstract}

Kata Kunci: Kinerja bisnis, Orientasi pasar, Inovasi produk, Kemampuan pemasaran.

\section{PENDAHULUAN}

Pertumbuhan kinerja bisnis dipengaruhi oleh banyak faktor. Kinerja bisnis merupakan indicator dari kesuksesan suatu bisnis. Kinerja bisnis yang baik akan memajukan perusahaan menjadi lebih baik kedepan yang ditandai dengan semakin efisien dan efektif proses bisnis yang dilakukan. Setiap perusahaan pastinya ingin memiliki kinerja bisnis yang selalu positif. Untuk itu perusahaan harus melakukan evaluasi dan analisis tentang faktor apa saja yang dapat mempengaruhi kinerja bisnis.

Setiap perusahaan pasti ingin bisnisnya long term. Semakin berkembangnya teknologi, persaingan akan semakin ketat. Perusahaan harus selalu dituntut untuk mempunyai strategi atau inovasi yang bisa membuat perusahaan juga maju. Inovasi juga hadir karena dorongan dari sumber daya manusia yaitu para pahlawan perusahaan (karyawan).

\section{LITERATURE REVIEW}

Orientasi pasar adalah suatu budaya bisnis yang menghasilkan kinerja dengan menciptakan nilai pelanggan (Slater dan Narver, 2000). Orientasi pasar yaitu perusahaan fokus kepada memenuhi kebutuhan dan keinginan dari pasar. Tujuannya adalah untuk meningkatkan penjualan dan memuaskan pelanggan sehingga nantinya akan banyak pelanggan loyal baru berdatangan. Ketika perusahaan berhasil memuaskan pelanggan, maka perusahaan menciptakan nilai pelanggan yang tinggi atau sama dengan harga produk dari perusahaan. Untuk mengetahui kebutuhan dan keinginan pelanggan, tentunya perusahaan harus melakukan riset pasar dan segmentasi pasar terlebih dahulu kemudian barulah perusahaan membuat atau menyesuaikan dengan produk dari perusahaan. Tantangannya adalah 
kebutuhan dan keinginan konsumen yang terus berubah seiring berjalannya waktu. Maka dari itu riset pasar bukan hanya dilakukan sekali atau dua kali, tapi rutin. Tujuannya adalah untuk bisa terus menyesuaikan dengan kebutuhan dan keinginan pasar.

Inovasi produk adalah usaha yang dilakukan untuk merubah, meningkatkan, dan mengembangkan suatu produk agar lebih bisa meningkatkan penjualan dan bisa sesuai dengan target market. Menurut UU nomor 19 tahun 2002 bahwa inovasi merupakan suatu rangkaian pengembangan dengan menerapkan ilmu pengetahuan dan teknologi ke dalam sebuah produk. Inovasi bisa muncul karena beberapa faktor, yaitu adanya feedback dari pelanggan dan inisiatif ide dari karyawan. Tujuan dari inovasi produk adalah untuk meningkatkan kualitas produk untuk lebih baik, memenuhi kebutuhan pelanggan, menciptakan pasar baru di tengah masyarakat, mengembangkan dan mengaplikasikan pengetahuan dan wawasan, dan meningkatkan efisinsi dari produk. Dengan makin berkembangnya zaman, inovasi menjadi suatu hal yang penting untuk bisa lebih unggul dibanding kompetitor. Perusahaan juga bisa dengan melalukan kolaborasi dengan perusahaan lain untuk membuat sesuatu yang baru dan akhirnya bisa mendapatkan pelanggan baru.

Kotler dan Keller (2009) mendefinisikan kapabilitas pemasaran sebagai fungsi organisasi dan serangkaian proses untuk menciptakan, mengomunikasikan, dan memberikan nilai kepada pelanggan dan mengelola hubungan konsumen. Kapabilitas pemasaran menurut Saladin (2003) adalah sistem total dari kegiatan bisnis yang dirancang untuk merencanakan, menentukan orientasi pasar, mempromosikan dan mendistribusikan barang yang dapat memuaskan keinginan dan mencapai target pasar dan tujuan perusahaan. Tujuan dari kapabilitas pemasaran juga untuk meningkatkan penjualan, memaksimalkan keuntungan, meningkatkan branding perusahaan, dan lain-lain.

Kinerja bisnis merupakan akumulasi dari hasil aktivitas yang dilakukan dalam perusahaan itu sendiri (Prasetyo dan Harjanti, 2013). Voss dan Voss (2000) mendefinisikannya sebagai usaha pengukuran tingkat kinerja meliputi omset penjualan, jumlah pembeli, keuntungan dan pertumbuhan penjualan. Kinerja bisnis merupakan indikator dari kesuksesan suatu bisnis. Fairoz et al. (2010) menyatakan kinerja bisnis sebagai hasil dari tujuan-tujuan organisasi yang dicapai melalui efektifitas strategi dan teknik. 


\section{REFERENSI}

Lasmy, Dewi, Syahchari, D. H., Saroso, H., \& Hartono, H. (2019). Effect of market orientation, marketing capability, product innovation on performance. International Journal of Innovation, Creativity and Change, 10(8), 322-337. Retrieved from www.scopus.com.

Sefianti, Siska. (2020). Pengaruh Orientasi Pasar Dan Inovasi Produk Terhadap Kinerja Pemasaran (Studi Kasus Pabrik Tahu Lorong Koni 1 Kecamatan Jelutung. Retrieved from http://repository.uinjambi.ac.id

Anonym. (2021). Orientasi Pasar: Cara Kerja, Keunggulan dan Kelemahan. Available at https://cerdasco.com/orientasi-pasar/

Ayunda. (2020). Inovasi Produk : Pengertian, Tujuan, Fungsi dan Manfaatnya dalam Pengembangan Bisnis. Available at https://accurate.id/marketing-manajemen/inovasi-produk/ 